\title{
AS CONTRADIÇÕES SOCIAIS EVIDENCIADAS PELO NOVO CORONAVÍRUS E A VIDA DAS MULHERES NO CONTEXTO DE PANDEMIA
}

\author{
LAS CONTRADICCIONES SOCIALES REVELADAS POR EL NUEVO CORONAVIRUS Y LA \\ VIDA DE LAS MUJERES EN EL CONTEXTO PANDÉMICO
}

\section{THE SOCIAL CONTRADICTIONS EVIDENTED BY THE NEW CORONAVIRUS AND WOMEN'S LIFE IN THE PANDEMIC CONTEXT}

DOI: http://dx.doi.org/10.9771/gmed.v12i3.37149

\author{
Ariana Rocha Caldeira ${ }^{1}$ \\ Nívia de Morais Bispo²
}

\begin{abstract}
Resumo: A pandemia do novo coronavírus revela e potencializa as contradições da sociedade capitalista, que mostra a sua face mais destrutiva: o lucro acima das vidas, revelando assim, a sua insustentabilidade. Neste manuscrito, apontamos algumas contradições que são evidenciadas e potencializadas pela pandemia e os impactos disso para a classe trabalhadora, de forma geral, e para as mulheres, em particular. Historicamente submetidas à dominação-exploração e opressão de gênero, de raça e de classe, as mulheres sentem os impactos desta pandemia em seus corpos e vidas. Os índices de violência contra mulher e de feminicídio, em função do isolamento social, crescem a cada dia. A luta por uma sociedade sem opressão passa pela luta contra os antagonismos de classe.
\end{abstract}

Palavras-Chave: Capitalismo; Pandemia do coronavírus; Classe trabalhadora; Vida de mulher

Resumen: La nueva pandemia del coronavirus revela y potencializa las contradicciones de la sociedad capitalista, la cual muestra su característica más destructiva: el beneficio sobre la vida, revelando así, su insostenibilidad. En este trabajo, señalamos algunas contradicciones que son destacadas y potencializadas por la pandemia y los impactos de esto para la clase obrera, en general, y para las mujeres, en particular. Históricamente sometidas a la dominación-explotación y opresión por género, raza y clase, las mujeres sienten los efectos de esta pandemia en sus cuerpos y vive. Las tasas de violencia contra las mujeres y el feminicidio, debido al aislamiento social, están creciendo cada día. La lucha por una sociedad sin opresión implica la lucha contra los antagonismos de clase.

Palabras-clave: Capitalismo; Pandemia de coronavirus; Clase obrera; Vida de mujer

Abstract: The new coronavirus pandemic reveals and intensifies the contradictions of capitalist society, which shows its most destructive face: profit above lives, thus revealing its unsustainability. In this manuscript, we point out some contradictions that are highlighted and enhanced by the pandemic and the impacts of this for the working class, in general, and for women, in particular. Historically subjected to domination-exploitation and oppression by gender, race and class, women feel the impacts of this pandemic on their bodies and lives. The rates of violence against women and femicide, due to social isolation, increases every day. The struggle for a society without oppression involves the struggle against class antagonisms.

Key words: Capitalism; Coronavirus pandemic; Working class; Woman's life

"...Quando a bistória se torna farsa E outubro não é mais um mês. 
A pandemia da COVID-19, doença ocasionada pelo novo coronavírus, é um fato histórico ao movimento da sociedade contemporânea, sobretudo por sua determinação relacional às estruturas do modo de produção capitalista. Sem nenhum compromisso com a vida humana, o capital segue sua agenda de saída da crise - sanitária, política e econômica - explorando a natureza e a força de trabalho alheia sob uma lógica ainda mais perversa e predatória. Em detrimento de uma política de combate à crise sanitária e a tudo que ela potencializa para grande parcela da sociedade, os imperialistas concentram suas forças no enfrentamento ao declínio das suas taxas de lucro e ao esgotamento do neoliberalismo, ampliando a retirada de direitos e meios de existência da classe trabalhadora (PEIXOTO et. al., 2019), especialmente de seus setores de base.

A alta transmissibilidade do vírus SARS-CoV-2 paralisou, em determinada medida, a vida coletiva - e diversos campos de trabalho também paralisaram suas atividades -, levando a dinâmica social a níveis cada vez mais precarizados. Tal dinâmica escancara taxativamente a ideologia individualista, o caráter neoliberal e necropolítico da maioria dos governos mundiais, que intensificam o sistema de exploração da riqueza produzida pela classe trabalhadora. O processo de falência das relações de produção capitalistas pode ser percebido pelas fortes investidas e manifestações destes governos, articulados à burguesia e ao grande empresariado, para pôr fim ao isolamento social com o objetivo de retomada dos trabalhadores aos seus postos produtores de maisvalia, secundarizando a defesa da existência. Assim, o capital escancara deliberadamente a sua face: o lucro acima das vidas.

Estes antagonismos da estrutura econômica reverberam toda a superestrutura que se ergue sobre ela. Combinadas, intensificam as desigualdades a níveis imensuráveis. O desmonte do sistema público e a falta de investimento nos setores essenciais, como saúde, educação e assistência social, mostram que o que temos vivido com a pandemia não pode ser explicado como um fim em si mesmo, pois é reflexo da negligência do Estado capitalista, concomitante à necessidade da classe dominante em segurar a crise já em curso. Em face disso, temos, de um lado, os interesses privados da expressão reacionária dominante neo e ultraliberal, do outro, as tentativas de sobrevivência da classe trabalhadora frente à precariedade das condições de existência.

No que tange às mulheres, o contexto determinado pela crise sanitária - mas também pela crise social própria da estrutura econômica -, e a exposição às condições de exploração e dominação da sociedade capitalista e patriarcal, torna mais intensas as contradições de seu modo de vida. Universalmente, este cenário torna mais difícil a condição específica dos grupos oprimidos, sobretudo pelo caráter neofascista e genocida do atual momento do modo de produção, claramente identificados na sobrecarga de abuso e violência - aumento do número de abortos clandestinos e feminicídios, de denúncias de violência doméstica, do extermínio da população negra, do desemprego da comunidade LGBT, do acometimento da saúde mental dessas categorias; 
das mães e dos filhos/as de nossa classe. No presente texto, identificamos como a pandemia comprova e potencializa as contradições sociais e os impactos disso para a classe trabalhadora, de forma geral, e para as mulheres, em particular.

\section{COVID-19: a pandemia que evidencia as contradições da sociedade capitalista}

No último onze de março, a Organização Mundial da Saúde (OMS) considerou o novo coronavírus (SARS-CoV-2) como uma pandemia ${ }^{4}$. Até o dia 04 de outubro foram confirmadas aproximadamente trinta e cinco milhões de pessoas infectadas (34.904.974) e mais de um milhão de mortes (1.033.516) em todo o globo. No Brasil, são quase cinco milhões de casos confirmados até esta mesma data (4.906.833) e aproximadamente cento e cinquenta mil mortes (145.987). Representando cerca de 15\% das mortes em todo o mundo, o Brasil perde apenas para os Estados Unidos, que registra até aqui 208.644 mortes $^{5}$.

É fundamental que a análise dos impactos da pandemia leve em consideração a sua relação com a estrutura do atual modelo de produção, tendo em vista as múltiplas determinações que fazem de um fenômeno aquilo que ele é. Os números alarmantes nos fazem pensar, por vezes, que essa é a maior crise sanitária vivida no mundo e, mais que isso, que nada podia ser feito para evitá-la. Mas isso é uma falsa verdade. Ao longo da história a humanidade enfrentou diversas pandemias, em contextos tão ou mais caóticos quanto o nosso. A Peste Negra, por exemplo, que durou 7 anos num cenário de guerra e fome, matou cerca de 200 milhões de pessoas. Em nossa memória, pandemias acometem vidas desde a antiguidade ${ }^{6}$. Com isso não dizemos que esta não possa se configurar em algum momento como a pior. Este devir dependerá das formas como a sociedade lidará com isso, objetiva e subjetivamente. O fato é que essa história entra em cena de tempos em tempos, não como tragédia, mas como farsa, diria Marx (2011).

A tradição de todas as gerações passadas é como um pesadelo que comprime o cérebro dos vivos. E justamente quando parecem estar empenhados em transformar a si mesmos e as coisas, em criar algo nunca antes visto, exatamente nessas épocas de crise revolucionária, eles conjuram temerosamente a ajuda dos espíritos do passado, tomam emprestados os seus nomes, as suas palavras de ordem, o seu figurino, a fim de representar, com essa venerável roupagem tradicional e essa linguagem tomada de empréstimo, as novas cenas da história mundial (MARX, 2011, p. 25-26).

Pensemos, agora, no cenário da conjuntura atual. Os avanços do último ciclo de lutas aqui no Brasil, apresentados pelo Partido dos Trabalhadores (PT) - política de cotas, programas de moradia e renda -, ainda que não abalassem as estruturas da ordem vigente, porque nunca passaram de uma política de conciliação de classes, conjuraram “espíritos” de um passado autoritário, liberal, extremista, genocida, racista e fundamentalista, dando vida ao personagem Jair Messias Bolsonaro; mas, antes, provocaram o impeachment da presidenta Dilma Rousseff, elevando à presidência da República Michel Temer - que ajudou a pavimentar o terreno sobre o qual essa nova narrativa se ergue. Não nos esqueçamos de que o teto dos gastos, a reforma do ensino médio, a reforma trabalhista, o fim do imposto sindical e tantas outras medidas que acirraram a contradição entre capital 
e trabalho são fruto do governo anterior. Por sua vez, Bolsonaro intensifica cada um desses elementos do passado em ultrageneralizações e atua muito bem na representação de novos enredos - que entram em cena como farsa.

Explicamos. Toda experiência vivida pela sociedade é acumulada em forma de conhecimento e transmitida para as gerações seguintes, graças à possibilidade de o ser humano desenvolver funções psíquicas superiores e elevar a sua consciência a graus de complexidade cada vez maiores (LEONTIEV, 1978; VYGOTSKI, 2012). Precisamente por essa capacidade de acumulação, registro e transmissão do conhecimento é que a produção humana sempre será “[...] resultado da atividade de toda uma série de gerações, que, cada uma delas sobre os ombros da precedente [...]" desenvolveu, elevando, deste modo, as produções a níveis cada vez mais elaborados (MARX E ENGELS, 2007, p. 30). Isso é facilmente perceptível no campo da ciência e tecnologia.

Ora, o grau de desenvolvimento das ciências e das tecnologias alcançado até aqui, nos permite, enquanto humanidade, antever tragédias e, portanto, minimizar os seus impactos, quiçá evitá-las. O que temos visto nos últimos meses, com as queimadas da Amazônia, do Pantanal e do Cerrado, são fenômenos previstos há anos por cientistas, negligenciados pelo estado liberal burguês/genocida que, contrariamente, incentiva ações criminosas como projeto político - favorecendo as grandes corporações ruralistas para fomentar movimentos ideológicos, que, intencionalmente, se opõem às explicações gnosiológicas, epistemológicas e ontológicas da realidade.

Não é diferente nas ciências médicas. Todo o conhecimento acumulado desde a antiguidade, com as experiências pandêmicas, possibilitaram à medicina e afins a desenvolverem vacinas, medicamentos, tratamentos para os diversos tipos de epidemias (AIDS, sarampo, poliomielite, caxumba, dentre outras). Em 2016, por exemplo, o Brasil comemorava a eliminação do sarampo em todo o território. Entre 2018 e 2019, porém, tivemos um surto com mais de dez mil casos e doze óbitos no país, principalmente na região Norte. Segundo diversos especialistas e a própria Organização Mundial da Saúde, o aparecimento de novos surtos de doenças que já deveriam ter sido extintas tem a ver com a queda no índice de cobertura de vacinação. Em 2017, por exemplo, a vacina Tetra Viral, que previne doenças como sarampo, caxumba, rubéola e varicela, teve o menor índice de cobertura, de 70,69\%, quando estima-se que o ideal é de, pelo menos, 95\% relação direta com o movimento antivacinação, que, de tempos em tempos, reaparece no bojo da realidade.

A OMS considerou, recentemente, o movimento antivacinação tão perigoso quanto os próprios vírus $^{8}$, porque ele inverte a lógica de progresso na prevenção de determinadas doenças, e gira a roda da história para trás. Não pensemos que estes movimentos são feitos por grupos isolados; ao contrário, são a representação de uma concepção anticientífica de mundo, defendida por grupos econômicos e políticos, conservadores e fundamentalistas, que investem em propagandas, via fake news, nos meios de comunicação mais acessados hoje, como as redes sociais, e colocam em cena versões distorcidas/falseadas da realidade - as quais atuam como coadjuvantes da ideologia burguesa. 
Dizemos com isso que mesmo diante da capacidade humana em antever alguns fenômenos, graças ao avanço da sua própria experiência com o mundo material, potencializada no processo de produção e reprodução da vida, contraditoriamente, ancorados em interesses econômicos, políticos e ideológicos, reaparecem à cena espíritos de um passado de retrocessos, que colocam em xeque as descobertas científicas e a importância delas para a humanidade. As respostas para a pergunta "por que essas contradições existem?" só podem ser encontradas na própria natureza do modo de produção capitalista, e na história da luta de classes como um todo. Pois,

A intensa expansão do coronavírus pelo mundo, até ser considerado o quadro pandêmico em 11 de março de 2020 (quando já se contabilizava oficialmente 118 mil infectados em 114 países e 4.291 mortes) tem, obviamente, duas razões: (1) a capacidade latente e natural do próprio vírus encontrar em células humanas "afinidade" reprodutiva, (2) mas principalmente as condições com que esses humanos interagem inevitavelmente dentro dos quadros socioeconômicos específicos. O que se sabe, em termos oficiais, é que os espaços mais propícios à expansão da COVID-19 são aqueles que têm forte interação econômica: espaços densamente urbanizados, com grandes mercados de consumo (como em Wuhan) e grande indústria turística, como nas principais cidades europeias, além de Nova York, nos EUA. Por isso mesmo, o COVID-19 é confundido como "doença de rico", "doença de turista". Isso nos diz mais sobre os processos de urbanização e adensamento populacional, sobre as condições com que desigualmente as pessoas transitam pelo mundo, sobre a natureza predatória da indústria do turismo global, sobre a própria natureza da "globalização", do que propriamente sobre um vírus (MENEZES, 2020, s/p).

Pois bem, a análise de Menezes (2020) reforça a ideia de que a forma como a pandemia tem se alastrado pelo mundo diz muito mais sobre as formas universalizadas das relações econômicas capitalistas (relações de troca, de valor, de mais-valor, de exploração, etc.) do que propriamente sobre a natureza do vírus. O estágio vigente do capitalismo, em sua fase imperialista, que mundializa e integra o caráter da produção pelas Cadeias Globais de Produção, não ocorre senão sob uma lógica de desigualdade e domínio político/econômico dos países centrais sobre os periféricos. Quer dizer, a divisão internacional do trabalho, que coloca no cerne da questão a concorrência entre os países pelo domínio do capital financeiro, tem efeitos contraditórios e nocivos à humanidade.

É oportuno aos detentores da riqueza, e aos que a gerencia, atribuir à causas naturais a crise que está em curso. O vírus, que, em última instância, evidencia as contradições próprias do modo de produção capitalista, passa, nesta lógica, a ocupar o papel central na justificativa das contradições sociais tornadas evidentes neste contexto. Reconhecemos que sim, que o vírus potencializa o agravamento das condições de vida, mas isso poderia não ocorrer se toda a ciência, e a produção, de forma geral, não estivessem sob o comando de uma parcela ínfima da sociedade que universaliza a níveis extremos os seus interesses.

Mendes e Carnut (2020) destacam que em cenários como o atual, em que o capital precisa recuperar seus lucros aquecendo a economia e o mercado, a saída para salvar o capitalismo não ocorreria sem uma superexploração do meio ambiente, resultando, assim, num desequilíbrio do ecossistema. No Brasil, temos uma ofensiva aos povos originários e o aniquilamento das dinâmicas ecológicas e dos recursos florestais que impedem qualquer forma de prevenção contra o aparecimento de novos patógenos da natureza do coronavírus, 
por exemplo. A expropriação das terras indígenas revela " [...] o processo histórico de separação entre produtor e meio de produção" (MARX, 2013, p. 786), que coloca sob o domínio do capital aquilo que restou de propriedade não submetida à lógica de extração de mais-valia.

Ou seja, este cenário se configura como uma face da "assim chamada acumulação primitiva", tendo em vista que "a relação capitalista não pode ser senão o processo de separação entre o trabalhador e a propriedade das condições de realização de seu trabalho, processo que, por um lado, transforma em capital os meios sociais de subsistência e de produção e, por outro, converte os produtores diretos em trabalhadores assalariados" (Idem, Ibidem), ou, o que é muito mais predatório, tira de cena os potenciais trabalhadores assalariados - covardemente exterminados pela política genocida do Estado burguês.

“O agronegócio, por meio de seu projeto ultra-neoliberal, organiza-se em torno de esforços de empresas sediadas nos países capitalistas industrializados mais avançados para saquear a terra, superexplorar o trabalho e os recursos dos países periféricos e dependentes" (MENDES E CARNUT, 2020, s/p). Isso, combinado com o crescimento da produção de commodities, com as fazendas industriais e com a ruptura de ecossistemas, criam as condições para o surgimento de novos patógenos que ameaçam o mundo todo (Idem, Ibidem). A pandemia do novo coronavírus poderia ter sido evitada, mas sob a lógica do capital isso não se apresenta como possibilidade.

As explicações místicas dos economistas do mercado, que afirmam que a economia voltará a crescer em 2021, passada a pandemia da covid-19, reduzem a crise que se arrasta há algum tempo a um papel secundário e, mais que isso, joga toda a responsabilidade da crise econômica à pandemia. Mais uma vez, uma tentativa de falseamento da realidade, tendo em vista que na dinâmica do capital é recorrente e inevitável a existência de crises econômicas, enraizadas na tendência à queda das taxas de lucro.

A concorrência intercapitalista coloca em movimento a busca por inovações tecnológicas, que aumentam a produtividade e, por consequência, a produção das mercadorias. Em decorrência disso, e também do aumento da exploração do trabalho, o ciclo em sua fase inicial eleva a expansão da economia. Contudo, no seu desenvolvimento, a alteração da relação entre capital constante e capital variável provoca uma queda na taxa de mais-valia. Na medida em que a queda da taxa de lucros atinge patamares que inviabilizam novos investimentos, os detentores dos meios de produção reduzem produção e reinvestimentos. Tal processo se realiza ao mesmo tempo em que o ritmo de absorção das mercadorias pelo mercado apresenta uma redução. Isto explica porque uma das faces das crises cíclicas do sistema capitalista é a superprodução. Desta queda da taxa de lucros resulta a desvalorização das ações e a instabilidade econômica e política, que geram um efeito em cadeia na esfera dos investimentos.

A crise pela qual passamos atualmente é a expressão da finalização de um ciclo econômico que se iniciou após a crise de 2007/2008. Segundo dados apontados pela "Crítica da Economia", a curva de crescimento do PIB registrou a) queda de 7,06\% em agosto em relação ao mesmo trimestre de 2019; e b) queda de $9.54 \%$ do crescimento anual real nos últimos quatro trimestres (dados publicados em 30 de junho). Há, nesse 
movimento, previsões de quedas menores no terceiro trimestre - que não significa uma estabilidade (se sim, num patamar muito baixo) ou tendência ao crescimento. Vale destacar que "Desde o início da crise (29 de fevereiro), quando o WEI registrou o último sinal positivo (+1.58\%), a curva da atividade econômica desabou abruptamente até seu ponto mais baixo deste período de crise (-11.45\%) em 25/abril. Um desabamento de quase 13 pontos percentuais frente ao índice de 29/fevereiro” (MARTINS, 2020, s/p).

Sem oscilações mais bruscas na metade que resta deste $3^{\circ}$ trimestre/2020, a linha vermelha do crescimento do PIB anual real deste trimestre - a ser publicada em 30/09/2020 - mostrará taxa dentro desta faixa atual do WEI de $-7.0 \%$. Mas esta é uma queda verdadeiramente catastrófica.

Primeira e importante conclusão: ao contrário das perspectivas dos economistas do imperialismo de que a partir deste $3^{\circ}$ trimestre/2020 a economia começaria a subir, como vimos acima, o que se observa até agora é exatamente o oposto: a economia mundial não sobe nem sai de baixo (MARTINS, 2020, s/p).

Ainda em 2019 a economia mundial já apresentava sinais de esgotamento. Dados apresentados pelo International Monetary Fund", já apontavam para uma "desaceleração sincronizada", tendo em vista a) o rebaixamento da previsão de crescimento naquele ano para 3\%; b) a redução do PIB mundial em 0,8\% até 2020, sobretudo pelas tensões comerciais entre Estados Unidos e China; c) a contração da indústria e do comércio mundial, que no primeiro semestre de 2019 teve um crescimento de apenas 1\% - o mais fraco desde 2012; d) sinais de abrandamento no setor de serviços, tanto nos Estados Unidos quanto na área do euro; e) previsões de queda no crescimento, tanto das economias avançadas quanto das emergentes, com queda de $0,6 \%$ em relação a 2018; f) a intensificação das tensões comerciais e geopolíticas, dentre outros diversos determinantes.

O fato é que a crise econômica em curso não é resultado do estado pandêmico atual. A pandemia, neste contexto, desempenhou a função de acelerar e potencializar todas as previsões de desaceleração da economia e, com ela, o agravamento das condições de vida das populações mais pobres em todo o mundo. Isto acontece porque a forma que o modo de produção capitalista encontra para sair da crise reúne um conjunto de medidas que implicam uma ofensiva aos direitos da classe trabalhadora.

Ou seja, a classe trabalhadora é a parcela da sociedade que, além de produzir toda a riqueza, arca com todo o ônus das crises. A conta da crise é paga pelos trabalhadores com suas próprias vidas; e isso não é uma metáfora. Num contexto de pandemia essa expressão é realidade concreta, porque os lucros dos capitalistas estão acima de qualquer vida humana. Se olharmos para os dados sem filtros ideológicos e romantizados da realidade, identificamos rapidamente quem mais morre e quem mais sofre com os impactos da pandemia. Ao contrário do que se tem propagado de que o coronavírus "não escolhe classe", as condições desiguais próprias deste sistema nos provam que sim, que a parcela mais afetada com esse surto pandêmico é o proletariado e os setores mais precarizados que o compõem.

O Brasil ultrapassou a marca dos 12 milhões de desempregados no primeiro trimestre deste ano ${ }^{10}$. Ricardo Antunes (2020) estima que esse número pode ter chegado a 40 milhões, se considerados os informais, os intermitentes e os uberizados. Em pesquisa recente, o DIEESE ${ }^{11}$ (Departamento Intersindical de Estatística 
e Estudos Socioeconômicos) chama a atenção para o fato de que a pandemia tem afetado principalmente os trabalhadores mais precarizados. Para se ter ideia, cerca de 13\% das pessoas (11,9 milhões delas) que tinham ocupação no primeiro trimestre deste ano, não estavam mais trabalhando no segundo trimestre. Além do mais, os mais afetados são aqueles com menor proteção trabalhista - 31\% são os trabalhadores domésticos sem carteira assinada; $23 \%$ trabalhadores do setor privado sem carteira assinada; $21 \%$ trabalhadores familiares auxiliares; e 18\% trabalhadores autônomos. Mulheres, negros, jovens e trabalhadores com baixa escolaridade também foram os mais afetados nesta pandemia, segundo esta mesma pesquisa.

O capital segue, assim, a sua agenda de saída da crise e, por sua vez, a classe trabalhadora luta para não morrer - de covid-19, de fome, pela violência policial. Ao liberar $\mathrm{R} \$ 1,216$ trilhão para o mercado financeiro ${ }^{12}$, enquanto libera $\mathrm{R} \$ 123,9$ bilhões para o pagamento do auxílio emergencial ${ }^{13}$, o Estado escancara a sua face neoliberal, transformando dívidas privadas, sobretudo as dos bancos, em dívidas públicas. E o faz numa correlação de forças bastante favorável. Contraditoriamente, a liberação do auxílio emergencial acontece como resultado de luta política numa correlação de forças nada favorável à nossa classe. Expressão disso é o valor que inicialmente era de $\mathrm{R} \$ 600$ e agora de $\mathrm{R} \$ 300$-, e todo o emaranhado de contradições que disso decorre.

Pois bem, o salário mínimo necessário, calculado pelo DIEESE ${ }^{14}$, apresenta um aumento de janeiro até setembro deste ano de $\mathrm{R} \$ 545,14$ - valor que já é maior que os aumentos de 2018 ( $\mathrm{R} \$ 207,92)$ e de 2019 $(\mathrm{R} \$ 413,84)$ num período compreendido entre janeiro e dezembro. O salário mínimo necessário hoje, calculado a partir das necessidades mínimas de existência, é de $\mathrm{R} \$ 4.892,75$. Ora, se o salário nominal $(\mathrm{R} \$ 1.045,00)$ representa pouco mais de $20 \%$ do salário necessário, imagina o auxílio emergencial. Essa contradição acentuada aumenta, de modo agressivo, a piora das condições de vida dos setores de base da classe trabalhadora. Enquanto o preço do feijão, do arroz, o gás, a luz, o telefone "não cabem no poema", como diria Ferreira Gullar ${ }^{15}$, os homens continuam sem estômago.

O estado de exceção que encontra terreno fértil num contexto de pandemia, restringindo o exercício dos direitos humanos em nome da preservação da vida, traz à tona um paradoxo. Ao mesmo tempo em que é real a necessidade do isolamento social para a contenção da propagação do vírus, o controle institucional sobre os corpos e sobre os grupos sociais cresce ao ponto de decisão de quem pode existir e quem pode sucumbir, legitimando, de tal modo, a normativa do direito de matar. Tomando de empréstimo o conceito de necropolítica desenvolvido pelo filósofo Achille Mbembe, o Estado decide quem morre e quem vive, bem como de que maneira morrerão e viverão as pessoas. Não nos surpreende o fato de o atual presidente do Brasil expressar, em vários de seus pronunciamentos, a banalização da vida; não de todas elas, mas daquelas que vivem em condições de vulnerabilidade social, confirmando, como já dissemos mais acima, o caráter genocida e eugenista deste governo ${ }^{16}$. O Estado, amparado por esse necropoder ou, como diria Mbembe, o Estado necroliberal "[...] sempre operou com a ideia de que alguém vale mais que os outros. Quem não tem valor pode ser descartado"17.

A construção dessa política não se inicia no governo Bolsonaro, é verdade. Contudo, é neste governo que ela consegue integrar processos antes dispersos - militarização e milicialização da política; adesão à 
plataforma ultraliberal e reacionária, sobretudo pela pequena burguesia e pelo setor pentecostal; fábrica de Fake News; lideranças ideológicas (Olavo de Carvalho); articulação com os Estados Unidos (Donald Trump), dentre outros elementos - dando-lhes um caráter distinto, de inspiração protofascista.

Pensemos no nosso Sistema Único de Saúde, que tem sido fortemente afetado com as investidas de privatização. O projeto de sucateamento do SUS não é algo recente, ele está em curso desde a sua criação, com o engajamento de setores conservadores e da burguesia ao estímulo às privatizações, às formas verticalizadas e burocratizadas de gestão. Do ponto de vista do subfinanciamento ou desfinanciamento, os ataques à saúde pública se expressam desde a Desvinculação das Receitas da União (DRU), que retira recursos da Seguridade Social para o pagamento da dívida externa, até a Emenda Constitucional n. 95. Esta última traz impactos incomensuráveis à saúde pública (e também à educação e a outras áreas sociais), uma vez que estabelece limites para despesas primárias até o ano de 2036, instituindo um novo Regime Fiscal no âmbito dos Orçamentos Fiscal e da Seguridade Social da União. Para se ter ideia dos impactos de tal medida, “[...] a estimativa de perda de recursos até 2036 no SUS será da ordem de R $\$ 415$ bilhões, levando em consideração uma média de crescimento do PIB em torno de $2 \%$ e uma projeção de IPCA de 4,5\%" 18 .

Esta lógica "reduz toda possibilidade de emancipação humana à perspectiva da contenção de gastos, formação de superávit primário, controle da inflação e manutenção da taxa de câmbio do país, em síntese, na diminuição dos gastos públicos como uma forma de evitar o déficit público" ${ }^{19}$. Concretamente, tais contradições se revelam, por exemplo, com: (a) a falta de equipamentos de proteção individual (EPIs) nos hospitais20; (b) a falta de leitos de Unidade de Tratamento Intensivo (UTIs); (c) a falta de profissionais da saúde, que sobrecarrega, por consequência, os profissionais em atividade; (d) a infraestrutura defasada de hospitais e Unidades de Pronto Atendimento (UPAs) 21 ; (e) a falta de testes para profissionais da saúde e população, em geral; (f) e a dependência da importação de equipamentos 22 . Soma-se, ainda, a isso, uma instabilidade política no governo, que foi o único do mundo a enfrentar a pandemia sem um Ministro da Saúde por mais de três meses.

Os impactos negativos da Emenda Constitucional n. 95 se estendem às diversas áreas sociais, fazendo com que essa transferência dos recursos das políticas públicas e dos direitos para o setor financeiro potencialize o agravamento das condições de vida dos setores mais vulneráveis da sociedade. Além disso, as Medidas Provisórias 927 e $936^{23}$, que flexibilizam os direitos trabalhistas em tempos de pandemia, mostram a verdadeira preocupação do Estado, a saber, salvar os lucros das empresas.

O isolamento social é a medida mais eficaz contra a propagação do novo coronavírus e o consequente colapso do sistema público de saúde. No entanto, numa sociedade marcada por desigualdades sociais de classe, de raça e de gênero, o isolamento social não é uma possibilidade para a maioria das pessoas. Ora, ficar em casa pode até ser a ação mais eficaz para evitar a rápida disseminação da doença. No entanto, contraditoriamente, maior parte da população brasileira sequer tem condições dignas de moradia ou mesmo moradia. O Brasil tem cerca de 6,9 milhões de famílias sem casa para morar, enquanto, por outro lado, 6,05 milhões de imóveis estão desocupados há décadas ${ }^{24}$. Estudo feito pelo urbanista Bernardo Loureiro, apresentado por Lu Sodré25, revela 
a disparidade entre periferias e centro quando analisado o percentual de domicílios com mais de dois moradores por dormitório. Os bairros periféricos chegam a ter 51\% de famílias com mais de duas pessoas por dormitório, enquanto esse percentual em bairros nobres é de apenas $2 \%$ - cenário que revela a impossibilidade de manter a distância necessária entre pessoas infectadas e outras pessoas que residem na mesma casa nas periferias deste país.

Quando pensamos nas pessoas em situação de rua, sequer temos um mapeamento preciso de quem são, quantas são, onde estão. Os dados que temos são uma estimativa feita, em 2016, pelo Instituto de Pesquisa Econômica Aplicada (IPEA), que fala em aproximadamente 102 mil pessoas vivendo nessa condição ${ }^{26}$. Ficar em casa não é uma opção para essas pessoas, que além de não terem casa, não têm também acesso a serviços de saúde, a medicamentos, à alimentação saudável, à água e produtos de higiene. Num país em que 48\% da população não possui coleta de esgoto e 35 milhões de pessoas não têm acesso à água tratada ${ }^{27}$, garantir as condições mínimas de higiene é impossível para essas pessoas. Assim, "A absurda construção de uma polarização entre economia e vidas humanas que naturaliza o sacrifício de determinadas populações, expondoas à morte em nome do perigo da fome, pode estar evidenciando que, no presente cenário, há muitas outras ameaças a combater, para além do coronavírus - Covid-1928".

Não é nenhuma surpresa para nós que negras e negros sejam mais vulneráveis em contexto de pandemia, tendo em vista que maior parte das pessoas que vive sob as condições supracitadas é negra. Segundo entrevista do professor e pesquisador Deivison Faustino (UNIFESP), concedida à Associação Brasileira de Saúde Coletiva (ABRASCO), "Graças a um histórico escravagista de nossa sociedade, mas, sobretudo, por um racismo que se atualiza em descaso e violência de Estado contra a população negra, nós somos a maioria absoluta nas favelas, nos cortiços, nas palafitas, na população de rua, nas cadeias, nos empregos precários ${ }^{29}$ ". Mais uma vez, a pandemia evidencia uma realidade que é histórica neste país: o racismo estrutural.

Os negros recebem salários inferiores às pessoas brancas, as mulheres negras recebem ainda menos e estão em postos de trabalho precarizados, com as piores condições de trabalho; a taxa de pobreza da população negra é de $32,9 \%$, a dos brancos $15,4 \%$; a taxa dos que não possuem esgotamento sanitário por rede de coletora ou pluvial são 26,5\% dos brancos, entre os negros é 42,8\%; no Rio de Janeiro $30,5 \%$ da população negra reside em aglomerados subnormais, $14,3 \%$ é percentuais das pessoas brancas na mesma situação; das que não possuem abastecimento de água por rede geral $17,9 \%$ fazem parte da população negra e $11,5 \%$ da população branca. ${ }^{30}$

Entendemos que é fundamental trazer dados como esses para que a compreensão do racismo não se movimente numa abstração e se limite a um debate que circula no campo da subjetividade. O racismo é estrutural porque faz parte de um emaranhado de relações contraditórias nas esferas econômica, política, jurídica, ideológica. Isso não significa que não exista um racismo individualista ou institucional, para tomar de empréstimos as contribuições de Silvio Almeida (2020), mas estes são a materialização de uma estrutura social que tem o racismo como um componente orgânico. "Ou seja, raça não é uma fantasmagoria, um delírio ou uma criação da cabeça de pessoas mal-intencionadas. É uma relação social, o que significa dizer que a raça se 
manifesta em atos concretos ocorridos no interior de uma estrutura social marcada por conflitos e antagonismos" (ALMEIDA, 2020. p. 52)

A falta de água, de saneamento básico, as péssimas condições de moradia, os subempregos (ou mesmo o desemprego), a falta de EPIs, os riscos que correm todos os dias aqueles que continuam trabalhando e precisam pegar transporte público, ou seja, a letalidade social que resulta de um estrutura histórica, social e política de desigualdade de raça e de classe, associada à comorbidades que atingem a população negra em maior número, como hipertensão, diabetes e, principalmente, anemia falciforme ${ }^{31}$, aprofundam ainda mais o racismo da sociedade brasileira.

Em síntese, os setores mais precarizados da classe trabalhadora (negras e negros, indígenas, moradoras e moradores de periferia, trabalhadoras e trabalhadores informais, mulheres, dentre outros) sofrem há muito com uma política de genocídio. Se não pelo genocídio protagonizado pela violência armada da Polícia Militar nas periferias deste país, que realiza um massacre dessa população, por um genocídio outro que também mata, mas pela negação das condições mínimas da existência humana, como alimentação, saneamento básico, saúde, educação, moradia, etc.; ambos gerenciados pelo Estado burguês. A pandemia se apresenta para a burguesia, inclusive, como uma arma genocida, eugenista, que pode varrer do mapa os subalternos. Não à toa, o presidente da República Jair Bolsonaro vai na contramão de todas as orientações da OMS e das entidades científicas quanto às medidas de contenção da propagação do vírus.

Pensando na mulher, especificamente, como o Estado brasileiro tem atuado na sua atenção no contexto da pandemia? O Ministério da Mulher, da Família e dos Direitos Humanos, por exemplo, ao invés de estar trabalhando na criação e ampliação de políticas de assistência às mulheres trabalhadoras, mães solo, trabalhadoras informais, moradoras de periferias, desempregadas, etc., criou o concurso de máscaras infantis "Pequenos heróis contra o vilão coronavírus"32, que premiou os criadores das melhores máscaras com uma viagem à Brasília. Seria cômico, não fosse a necropolítica brasileira mostrando a sua face feminicida, classista e racista.

A primeira vítima fatal do novo coronavírus no Rio de Janeiro, trabalhadora doméstica de 63 anos, que não teve nome divulgado, foi infectada pela patroa, que se contagiou em viagem que fez à Itália. Duas mulheres em condições antagônicas, “[...] empregada dormia no emprego, patroa viajou para Itália de onde retornou doente. A empregada morreu em um hospital público, foi enterrada em cemitério vizinho à casa de rua sem asfalto. A patroa mora no metro quadrado mais caro do Rio de Janeiro"33. Aqui ficam explicitadas as contradições dos privilégios de classe e gênero. Ser mulher numa sociedade ancorada no patriarcado e no machismo é lidar todos os dias com a dominação-exploração e opressão que estes elementos carregam. No entanto, os impactos vivenciados pelas mulheres variam em função da condição de classe, de raça, de diversidade de gênero. Como trabalhadora, a doméstica morta pelo coronavírus é uma expressão singular dos impactos que o capitalismo e os pilares que os sustentam trazem às vidas da classe trabalhadora, em geral, e às vidas das trabalhadoras, em particular. Compreendamos melhor esta relação. 


\section{A vida da mulher no contexto da pandemia do coronavírus}

O quadro de pandemia, que provoca o confinamento das pessoas dentro de suas próprias casas, acirra coléricas relações domésticas - invisibilizadas dadas as condições de isolamento e distanciamento social. A situação de vida das mulheres trabalhadoras, especialmente negras, reserva elementos particulares dos abusos patriarcais, expressos na sobrecarga de trabalho reprodutivo, no silenciamento de suas vozes, nas diversas formas de cerceamento e no sofrimento causado pela violência.

É importante reforçar que o contexto pandêmico agrava, mas não é ele que provoca tal situação. Segundo o Anuário Brasileiro de Segurança Pública ${ }^{34}$, de 2019, nos anos de 2017 e 2018 foram registrados mais de meio milhão de casos de violência doméstica (515.962). Dos casos de feminicídio registrados entre 2017 e 2018, que chegaram a 2.381, 61\% foram de mulheres negras; $88,8 \%$ das vítimas foram assassinadas pelos próprios companheiros ou ex-companheiros; e 65,6\% aconteceram na residência da vítima. Quanto ao estupro, dos 129.198 casos registrados neste mesmo período, 104.324 foram de mulheres. Estes números são assustadores, mas representam apenas 7,5\% das vítimas, pois só este percentual notifica os órgãos competentes. Destes números, 63,8\% representam as vítimas menores de 14 anos, das quais $81,8 \%$ são meninas; além disso, $75,9 \%$ delas possuem algum tipo de vínculo com o agressor (parentes, companheiros, amigos) - o que revela que a violência sexual é em geral praticada por pessoas de confiança e membros da própria família. Isso explica as subnotificações, associadas à falta de credibilidade, ao medo da vítima, ao silêncio como cumplicidade aos parentes, que se revelam também nos casos de estupro marital. Dados de $2016^{35}$ mostram que apenas 13,15\% dos estupros no Brasil praticados pelo cônjuge são denunciados. A violência sexual exercida pelos companheiros é extremamente complexa, porque, além do silêncio e do medo - causados por outros tipos de violência, como a psicológica, a moral, a patriarcal e mesmo a física - muitas mulheres sequer a identificam.

Dados do Datafolha ${ }^{36}$, divulgados em fevereiro de 2019, revelam que: (a) no Brasil, em um ano, 1,6 milhão de mulheres foram espancadas ou sofreram tentativa de estrangulamento; (b) 22 milhões passaram por algum tipo de assédio; (c) nos casos de violência, 42\% ocorreram no ambiente doméstico e, o que é ainda pior, mais da metade das mulheres (52\%) que sofreram violência não denunciaram o agressor ou mesmo procuraram ajuda. Ainda segundo esses dados, uma parcela grande das mulheres que sofreram violência $(76,4 \%)$ conhece o agressor - maior parte dos casos acontece dentro da própria casa da vítima, que muitas vezes é também a do agressor. A maior parte das vítimas de violência doméstica é negra, 55,9\%.

Em tal grau, precisamos denotar o aumento da violência de gênero intensificada pelo isolamento social, tendo os homens - como agentes da agressão - configurando as distintas formas de atacar mulheres e outras vítimas dentro dos espaços domésticos e intrafamiliares. Os fatores podem ser diversos, e variam desde a proximidade ou constante convivência entre agressores e vítimas, até a restrição de contato com grupos de apoio que comumente prestam auxílio. Aqui vale destacar a dificuldade de acesso a setores de acolhimento, denúncia e cuidado - já que a restrição de contato é a premissa de não adquirir o vírus. Além do mais, a preocupação em não expor amigos e familiares ao risco de contágio, associada à vulnerabilidade econômica que 
a grande maioria está exposta dentro das relações conjugais, são determinantes para que as vítimas não peçam ajuda.

Mesmo assim, as denúncias ao número 180 (canal de denúncia de violência contra a mulher) subiu $40 \%$ em meio a pandemia ${ }^{37}$. Os dados evidenciam um aumento significativo nos casos, embora sejam frágeis e o próprio documento reconhece isso - dada a multiplicidade e magnitude da violência contra a mulher não serem reveladas por eles em função das subnotificações. Outros dados ainda se mostram contraditórios, caindo as estimativas em algumas regiões e aumentando absurdamente em outras em relação a anos anteriores, o que possibilita a análise de que há uma dificuldade de acesso aos serviços que registram os casos, bem como fragilidade institucional em atender as vítimas a contento, devido a sobrecarga neste período.

Segundo nota técnica do Fórum Brasileiro de Segurança Pública, "Violência doméstica durante a pandemia de covid-1938", de 29 de maio, um dos maiores problemas que temos enfrentado é a dificuldade que as mulheres têm tido, em função do isolamento social, em denunciar os agressores. A nota traz um estudo de doze $^{39}$ estados brasileiros, feito mediante o fornecimento de dados pelos Tribunais de Justiça de cada estado. Os dados nos ajudam a desenhar o cenário. Em todos os estados houve redução dos registros de lesão corporal dolosa por decorrência de violência doméstica entre março e abril; em relação ao mesmo período em 2019, a redução média é de 25\%. Mesmo em São Paulo, onde foi implementado boletim de ocorrência eletrônico, a redução foi de 21\%. Em relação aos feminicídios, o aumento foi de 22,2\% - de 117 vítimas em março/abril de 2019 para 143 vítimas no mesmo período em 2020. "No Acre o crescimento chegou a 300\%, passando de 1 para 4 vítimas este ano; no Maranhão o crescimento foi de 166,7\%, de 6 para 16 vítimas; no Mato Grosso o crescimento foi de $150 \%$, passando de 6 para 15 vítimas".

Em relação aos homicídios de mulheres, apenas oito estados forneceram os dados. Nos chama atenção o estado do Ceará, que passou de 36 vítimas em 2019 para 61 vítimas em 2020, no período analisado. "Este dado é ainda mais preocupante quando verificamos que apenas 6,6\% de todos os assassinatos de mulheres foram classificados como feminicídio no Ceará, o que é muito pouco provável e pode revelar subnotificação deste crime no estado". Os registros de estupro também caíram; apenas o Rio Grande do Norte apresentou um crescimento de 118,8\% - fato que está ligado à ampliação da capacidade de cobertura do sistema de registros no estado. Outro número que apresentou queda foi o de concessões de medidas protetivas de urgência. Na variável "atendimentos no 190", a nota destaca o descaso/despreparo da Polícia Militar no atendimento às vítimas de violência contra a mulher, que por vezes é classificada como 'briga de marido e mulher'. Mesmo diante de tal descaso, temos um aumento das denúncias de 44\% em São Paulo no mês de março; de 33\% no Acre no mês de abril; e de 5,1\% no Rio de Janeiro em abril.

São distintas e não generalizadas as formas de violência, variando entre violência de gênero, violência contra mulheres, violência doméstica e violência intrafamiliar. Entendemos ser mais amplo o conceito de violência de gênero, que abrange "[...] vítimas como mulheres, crianças e adolescentes de ambos os sexos. No exercício da função patriarcal, os homens detêm o poder de determinar a conduta das categorias sociais 
nomeadas, recebendo autorização ou, pelo menos, tolerância da sociedade para punir o que se lhes apresenta como desvio." (SAFFIOTI, 2001, p. 116). Como apenas a ideia do gênero patriarcal dominante não é suficiente para assegurar a obediência das potenciais vítimas, o homem sente a necessidade de fazer uso da violência para manter seu projeto.

A problemática de gênero destaca-se como um fenômeno cruel de estruturas opressivas, que avança na modernidade enquanto crise aguda de caráter mais violento e doloroso (KOLLONTAI, 2005). No Brasil, especificamente, onde o conservadorismo restabelece fortemente os velhos costumes familiares com a eleição da extrema direita em 2018, a gestão bolsonarista tem na figura da Damares Alves (Ministério da Mulher, Família e Direitos Humanos) o que há de mais reacionário e conservador. Contrária ao movimento feminista e LGBT, e à pautas históricas das mulheres, a ministra defende a família tradicional sob a lógica dos preceitos cristãos ${ }^{40}$. Indo na contramão da laicidade do Estado, seu discurso veicula ideais patriarcais de dominação-exploração ${ }^{41} \mathrm{e}$ opressão, coadunando com a teoria da resignação e passividade que lhe imprime tamanho grau de distorção da realidade, que é incapaz de imaginar a possibilidade de libertação (MARCHEL, 1973) e de perceber que o lugar que ocupa hoje só lhe foi possível graças às lutas feministas.

A apresentação de uma figura feminina ultraconservadora frente a um ministério estratégico é uma expressão real da manutenção do projeto de sociedade patriarcal. O interesse dos setores tradicionais da ordem social capitalista em barrar qualquer processo revolucionário que culmine em igualdade social, sexual e de libertação da humanidade é reafirmado nos aparelhos hegemônicos com ações institucionalizantes do padrão social burguês. Na tentativa de enterrar os avanços do último ciclo de lutas no Brasil, e com eles, o levante das lutas anti-opressão, a extrema direita angaria perfis que censurem os movimentos revolucionários e, ao mesmo tempo, fortaleçam narrativas retrógradas para justificar suas ações ostensivamente atrozes.

Engels (2012) explica que o sistema patriarcal se enraíza nos antagonismos inaugurados pelo processo de desenvolvimento das forças produtivas, quando o modo de produção ainda se baseava em comunas - forma de vida mais duradoura do ser humano enquanto Homo sapiens. Nas comunidades primitivas, as mulheres eram protegidas do perigo para garantia da reprodução, mas nunca cerceadas de liberdade ou determinadas a trabalhos ou características específicas; a maternidade, por exemplo, era relegada pelo aleitamento, mas o desenvolvimento da criança era de cuidado de toda a comunidade. Ainda que houvesse uma divisão de trabalho e distinção sexual entre homens e mulheres, não eram relações de hierarquia que determinavam esta diferença.

Foi com o desenvolvimento do domínio técnico da humanidade sobre a natureza - técnicas agrícolas, de criação do gado e de elaboração de metais - que a lógica do trabalho excedente e do trabalho alienado se instaurou, estabelecendo uma forma de exploração e consequente divisão social e sexual hierarquizada. Combinadas, atuaram como forças impulsionadoras da acumulação de riquezas. Convertida em propriedade privada do homem, a riqueza - novas tecnologias e seres humanos escravizados -, não podia se diluir com a sua morte. Era preciso, pois, que os filhos a herdasse. Assim, ao juízo do ser social homem foi entregue a ser social mulher, que lhe devia fidelidade como forma de assegurar a indiscutível paternidade e herança. 
O desenvolvimento da família monogâmica, sustentada por essa lógica, substituiu aos poucos as uniões por grupos - pela exclusão progressiva dos parentes próximos e distantes e daqueles que tornaram-se parentes pelo casamento - e reduziu o matrimônio "à sua última unidade, à sua molécula biatômica: um homem e uma mulher" (ENGELS, 2012, p. 73). Deste mesmo processo, a humanidade gerou guerras para concentrar riquezas - incluindo nelas mais escravos, ou seja, força de trabalho humana explorada -, e modificou o modo de produção comunal para o escravocrata, as relações sociais de comunidades para famílias, e a configuração delas para monogamia heterossexual.

As formas atuais de união entre os sexos são contraditórias e complexas, por serem pautadas em princípios de decomposição, tendo como extremo o individualismo e mais dois fatores da psicologia contemporânea agravando a situação. Primeiro, a ideia do direito de propriedade sobre a outra pessoa, e sobre todos os aspectos de sua vida - seu corpo, suas relações, seus sentimentos, que nasce com a família monogâmica e a propriedade privada, como apontamos acima. Segundo, a desigualdade e preconceito entre os sexos em todas as esferas da vida (KOLLONTAI, 2005), que aponta para um panorama de inferioridade da mulher e dominação-exploração do seu próprio eu, quiçá da dinâmica de sua vida. Inferioridade legitimada por uma ideologia e uma cultura que defendem os valores da exploração. “A exploração econômica da mulher, a sua transformação em produtora sem direitos, ao serviço do proprietário - esposo ou do proprietário - pai, exigem a elaboração da ideologia e cultura adequadas, a organização dum sistema de educação que as transmitem. É evidente que não se trata dum ato único e total, mas dum processo que se elabora e refina durante os milênios em que a sociedade existe" (MARCHEL, 1973).

Essa mesma realidade em movimento possibilita as condições de ruptura com a lógica que a produz. Estudos apontam que em casos de violência, as mulheres sempre reagem tentando se defender do seu agressor de diferentes maneiras, mas, frequentemente, é necessário o auxílio de um apoio externo para que ela de fato consiga se livrar da violência. $O$ argumento de que elas não são, então, vítimas, por reagirem ou se manterem nestas situações por repetidas vezes ou longo tempo, está no fato de que a ordem patriarcal de gênero imposta dentro da sociedade em que vivemos, legitima (BOURDIEU apud SAFFIOTI, 2001) este estado-de-coisas; e esta legitimação social confirma-se pela reprodução da "quase totalidade dos membros da sociedade brasileira e de praticamente todas as demais existentes no momento atual" (SAFFIOTI, 2001, p. 121). Para a autora, este fenômeno deve ser analisado por dois ângulos: 1) a coletividade, onde os homens perenemente utilizam sua força física para dominar-explorar as mulheres, com autorização do projeto social em curso; 2) o individual, onde homens e mulheres, mesmo com raridade, conseguem viver relações baseadas em princípios de equidade, fora das regras de hierarquização, contrariando todo o contexto social.

Logo, diante da flexibilização do projeto, a ideologia dominante lança mão de ferramentas de reforço para validar a hegemonia de determinados aparelhos institucionais do capital, ampliando, desta maneira, a opressão e violência. A reação conservadora ao espaço que as mulheres e todas as categorias oprimidas vem ganhando nos últimos anos fica evidente com as investidas da plataforma de extremadireita, ultraliberal e 
anticomunista. A ofensiva aos direitos reprodutivos e as reformas trabalhistas, por exemplo, agravam a condição de vida das mulheres trabalhadoras - sobretudo das pretas periféricas - frente à dinâmica de superexploração da força de trabalho, em duplas, triplas ou maiores jornadas diárias, perpetuando as mesmas tarefas e violências as quais já eram incumbidas nossas ancestrais em modos de produção já extintos.

$\mathrm{Na}$ sociedade capitalista, sob a dinâmica da luta de classes, a condição de exploração do trabalho e da violência de gênero se altera e se renova de acordo com as necessidades da realidade em contradição. De acordo com Saffioti (1987), os sistemas dominantes atribuem diferentes papéis sociais a serem vivenciados universalmente pelas diferentes categorias de sexo. A socialização dos filhos, por exemplo, como tarefa imputada às mulheres frente a qualquer circunstância do movimento da vida de cada uma delas, sua atribuição ao espaço doméstico privado e consequente responsabilização por toda dinâmica, naturaliza-se como vida de mulhert2 - obrigatoriamente permeada de trabalho não remunerado e pela associação da maternidade como parte desta relação nuclear de exploração-dominação.

Para se ter ideia, em relação ao tempo destinado às tarefas domésticas, por exemplo, (a) as mulheres dedicam em média 21,3 horas por semana com afazeres domésticos e cuidado de pessoas, enquanto os homens 10,9 horas; (b) mesmo trabalhando fora, as mulheres cumprem 8,2 horas a mais que os homens que trabalham; (c) quando tanto o homem quanto a mulher não trabalham, a mulher chega a dedicar 11,8 horas a mais que os homens; (d) na condição de companheira, 97,7\% das mulheres realizam tarefas domésticas, enquanto os homens $84,6 \%{ }^{43}$. Quando se trata do cuidado com as crianças, há um predomínio da figura feminina como principal responsável. Em pesquisa do IBGE, de 2015, de 10,3 milhões de crianças com menos de quatro anos, 83,6\% tinham uma mulher como a primeira responsável${ }^{44}$.

Engels (2012) observa que a hierarquia entre o ser social homem e a ser social mulher na monogamia coincide, deste modo, como o primeiro antagonismo de classes, outrossim a opressão do gênero feminino pelo masculino como a primeira opressão de classes. Como movimento contraditório que é, a família nuclear monogâmica, e com ela a escravidão e as riquezas privadas, representa progresso e retrocesso simultaneamente. Ao mesmo tempo em que potencializa a elaboração das forças produtivas, o faz sob uma lógica perversa de dominação-exploração de um ser humano por outro - homem-mulher; homem- escravo.

Para sermos mais claras, a sociedade patriarcal investe em tornar natural o pensamento de que se nós mulheres podemos gestar e parir, também podemos cuidar e dar conta de todo o resto que diz respeito a estas novas vidas, bem como ao ambiente onde elas se desenvolvem. Portanto, o cuidado doméstico privado é imposto pela divisão sexual do trabalho às mulheres, e de maneira agravada, às mulheres negras - dado o período de escravismo dos povos africanos -, que são subordinadas ao jugo do padrão racista da sociedade, recebendo os menores salários por qualquer atividade desempenhada e estando quase sempre nas piores condições. Maioria nos empregos mais precarizados, em 2018, a renda da mulher negra média equivalia a 58,6\% $\%^{45}$ da de uma mulher branca. 
Ao tratar sobre emancipação das mulheres negras e escravidão, Davis (2016) retrata a condição destas mulheres no período "pós-libertação", onde ficavam condicionadas obrigatoriamente a empregos como serviços domésticos, no campo, na cozinha, na lavanderia e manufaturas. Aquelas que se empregavam na indústria, ficavam encarregadas "dos trabalhos mais sujos e com menores salários” (Idem, p. 95). De lá até aqui pouca coisa mudou. Herdamos desse período uma profunda desigualdade de raça que cria em nossa sociedade um racismo que é estrutural (ALMEIDA, 2020), pela sua relação com a instância econômica, desdobrando-se em processo político e histórico, que incorpora e supera as concepções individual e institucional atreladas aos panoramas da subjetividade e do Estado. Em outras palavras, o racismo - assim como o machismo e a misoginia - é decorrente da própria estrutura social, ou seja, da maneira como se constituíram "as relações políticas, econômicas, jurídicas e até familiares, não sendo uma patologia social e nem um desarranjo institucional" (Idem, p. 50). Isso explica que as ações, os comportamentos, as ideias de sujeitos ou de coletivos "são derivados de uma sociedade cujo racismo é regra e não exceção" (Idem, Ibidem)

Diante desta pandemia, as mulheres negras vivenciam uma opressão triplamente escancarada: a de classe, a de raça e a de gênero. O trabalho doméstico, por exemplo, tão invisibilizado historicamente, passou a ser pauta central nos diversos debates e meios de comunicação. Relatos de pessoas sentindo falta de suas empregadas e diaristas, reclamando da difícil jornada durante a quarentena, porque precisam lidar com as atividades domésticas e com o cuidado com as crianças cotidianamente - tarefas que antes do isolamento social eram terceirizadas - escancaram os privilégios estruturantes da sociedade capitalista e racista. Isto porque, "a ação dos indivíduos é orientada, e muitas vezes só é possível por meio das instituições, sempre tendo como pano de fundo os princípios estruturais da sociedade, como as questões de ordem política, econômica e jurídica" (ALMEIDA, 2020, P. 49). Dados de $2015^{46}$ mostram que das 5,7 milhões de trabalhadoras domésticas, 3,7 milhões eram negras.

O trabalho doméstico é então majoritariamente realizado por mulheres negras, racionalmente mal remunerado e historicamente desprovido de direitos. Embora a profissão tenha sido regulamentada em 2013, das 6,3 milhões de trabalhadoras (es) que prestam serviços domésticos, apenas 1,5 milhão têm carteira assinada. As (os) que atuam sem carteira assinada (2,3 milhões) e como diaristas (2,5 milhões) ${ }^{47}$ formam um grupo bastante vulnerável, sobretudo em contexto de pandemia. Muitas das que têm carteira assinada não foram dispensadas do trabalho, as que estão na informalidade continuaram trabalhando, se expondo cotidianamente ao vírus nos transportes públicos, nos supermercados, com o medo de levar o vírus para casa e contaminar os familiares, pois reconhecem as condições de moradia em que vivem.

O ideário que se construiu do "instinto feminino" de cuidar, naturalizado ao longo da história, foi apropriado inescrupulosamente no período da escravidão e produziu para a mulher negra a função social de cuidar, ao mesmo tempo, de sua senhora e seu senhor, de sua família, da de outros escravizados, e da sociedade escravocrata. Pensando no campo da saúde, a negação do processo de profissionalização às mulheres negras e indígenas, porque seus conhecimentos ligavam-se às práticas tradicionais de saúde, está intimamente ligada à 
estrutura racista-classista. O monopólio das práticas de saúde coube à categoria médica, que sustenta uma representação social de subordinação da enfermagem à medicina - composta hegemonicamente por pessoas brancas. A enfermagem, ao contrário, inferiorizada histórica e socialmente, tem negras e negros como maioria.

O maior estudo sobre o perfil da enfermagem no Brasil, realizado pelo Cofen/Fiocruz (2013), mostra que há, aproximadamente, 3,5 milhões de trabalhadores das diversas profissões da saúde, e a equipe de enfermagem compõe cerca de $50 \%$ destes trabalhadores, sendo que $86 \%$ desta equipe são mulheres, $0,6 \%$ (10.132) são indígenas e 53\% (955.578) são negras e negros, que compõem 46,5\% dos profissionais da enfermagem que atuam nos Serviços Públicos de Saúde no Brasil. Vale ressaltar que $47 \%$ dessa categoria que atua na rede pública afirma ter sofrido discriminação racial e $78,5 \%$ discriminação de gênero 48 .

São estas profissionais que estão na linha de frente no combate ao coronavírus, juntamente com outras profissionais negras, como copeiras e higienizadoras, expondo-se todos os dias às condições precarizadas do trabalho na saúde, com falta de EPIs, falta de recursos humanos, extensas jornadas de trabalho. "Mulheres negras, são maioria dos profissionais que atuam nas unidades de saúde, principalmente nos territórios marginalizados, desde os antigos hospícios, no século XIX, às periferias e favelas" ${ }^{49}$. E são essas mesmas mulheres que ao saírem de seus postos de trabalho enfrentam todas as outras contradições vivenciadas pela população negra neste país, somadas às opressões de gênero dentro de suas casas.

É importante o destaque de que as relações sociais concretas são, em si, relações de identidade, porém, na sociedade capitalista, elas são tratadas a partir de substratos ideológicos, e "não se pode compreender uma ideologia por meio de concepções igualmente ideológicas" (ALMEIDA apud HAIDER 2019, p.9). No tratamento de uma identidade enquanto ideologia, os indivíduos, como seres sociais capitalistas, acabam por praticar manifestações tangíveis ao assujeitamento próprio do exercício político, econômico e histórico das instituições às quais estão inseridos. O modo de produção capitalista, alicerçado no patriarcado e em estruturas racistas, vem alimentando ao longo da história um contexto sexista, explorador e dominador. Sobre seu firmamento, o poder burguês, branco, heterossexual e misógino determina uma teia sistemática de relações sociais fundamentadas nos princípios dominantes, reforçando um aparato ideológico pautado em processos de naturalização desta discriminação.

Contudo, não podemos partir de uma atribuição excepcional do gênero masculino como "naturalmente" machista e dominador, pois o patriarcalismo é um comportamento edificado dentro das estruturas históricas da totalidade humana, das quais não nos reconhecemos enquanto produtos e produtores desta realidade objetiva, tornando-nos alienados dela e estranhados uns dos outros enquanto seres também humanos nas nossas relações sociais. Tendo em vista que opressão e exploração estão intimamente ligadas, sendo a primeira resultado do desenvolvimento da segunda (MARCHEL, 1973), a luta da mulher não é contra o homem, mas contra a ordem social.

Certas de "que a inferioridade feminina é exclusivamente social" (SAFFIOTI, 1987, p. 16), assim como a subalternidade de qualquer ser humano frente a outro, entendemos que essa realidade deve ser mudada no âmbito das lutas sociais. Neste ensaio, em que pautamos sobre a vida das mulheres, articulamos, portanto, o 
feminismo classista enquanto luta social engajada na superação da condição feminina a partir da modificação da sociedade. Hooks (2018) compreende o feminismo como o instrumento mais contundente na luta por uma nova forma de relação social, principalmente pelo seu entendimento de que este movimento é de caráter antissexista, para acabar com a exploração sexista e a opressão. Ele, por si, não pode se afastar da dimensão social, tornando-se ponto de partida e chegada, assim como o movimento anticapitalista precisa superar os obstáculos do machismo, sexismo, racismo, LGBTfobia, xenofobia, sem reduzi-los a identitarismos vazios (HAIDER, 2019). O grande desafio dos setores organizados da classe trabalhadora é aglutinar as massas, tornando revolucionárias as pautas dos movimentos anti-opressão, modificando as estruturas de classe e suas pautas ideológicas.

O processo de constituição da subjetividade humana é política e de bases historicamente econômicas. Por isso, a identidade do ser social deve ser considerada como dado de análise da teia de suas relações materiais. A personalidade feminina e de qualquer ser humano não está dada subjetivamente, por isso a necessidade dessa objetivação, que só reforça àquilo que Simone de Beauvoir aponta: não nascemos mulheres, tornamo-no-las. Na mesma medida, o movimento anti-opressão - vulgarmente chamado de identitário - necessita apoiar-se num horizonte de mudança das próprias estruturas sociais que produzem os aparelhamentos das identidades, afinal, sem converter a ordem, seremos "no máximo, uma versão melhorada e menos sofrida daquilo que o mundo historicamente nos reserva" (ALMEIDA apud HAIDER, 2019, P. 13, grifos nossos). Somos formadas/os tanto pela multiplicidade de determinações que acontecem ao mesmo tempo (mais imediatas) quanto por aquelas que se desenvolvem ao longo do tempo (históricas), ambas marcadas por correlações de forças. Dito de outra forma: "de um ponto de vista ontológico, a unidade (material) do ser tece-se de multiplicidade - na sincronia de um corte que lhe surpreende a arquitetura de estruturação e na diacronia de um processo que lhe enriquece a concreção, enquanto positividade, fluência e transformação" (BARATA-MOURA, 2006. p. 135).

Ora, compreender o ser nessa complexidade histórica do devir é laborioso e só é possível quando superamos os limites ônticos da realidade concreta, quando fazemos a ultrapassagem da superficialidade, da análise fenomênica - e é aqui que se movimenta a pauta da política identitária - à radicalidade. Daí a importância da crítica ontológica. Ela é capaz de possibilitar uma compreensão para além da aparência e criar as condições para uma prática transformadora - que só se valida na medida em que parte de uma verdade objetiva.

Neste sentido, tanto o pensamento quanto a prática transformadora se enguem sobre uma base material. O exercício de olhar para a realidade e identificar o projeto de sociedade em curso é fundamental para que o nosso agir não se resuma à práticas individualistas e subjetivas. É responsabilidade coletiva a (re)configuração humana do ser pautada na concreticidade histórica.

É tarefa da classe trabalhadora e dos grupos oprimidos organizar-se em torno de um projeto anticapitalista e anti-opressão. Num momento como este, em que estamos na defensiva, torna-se imperioso o esforço de compreensão da realidade, porque só é possível mudar aquilo que se conhece. Esse texto não é uma síntese acabada, ele é parte de um movimento de constatação da realidade e de chamamento para a luta 
organizada, para a disputa por um projeto de sociedade em que sejamos iguais, do ponto de vista social; diferentes, nas nossas individualidades; e livres de toda a dominação-exploração e opressão, na totalidade das relações sociais.

\section{Considerações Finais}

No limite do que foi possível produzir, na condição de mulheres num contexto de pandemia, em que as nossas vidas também são marcadas por todas essas contradições que afetam diretamente a nossa produção acadêmica ${ }^{50}$, consideramos que o coronavírus escancara, de maneira bastante dolorosa, os limites de uma sociedade dividida em classes sociais antagônicas, os limites do capitalismo. Ao fazer isso, coloca a necessidade expressa de uma nova forma de organização social que dê conta de superar os processos contraditórios desta sociedade. O modo de produção capitalista, gerenciado pela burguesia e pelo Estado, expõe, através de uma crise sanitária global, a sua incapacidade de mediar as relações que os seres humanos estabelecem com a natureza e com eles mesmos.

O agravamento da crise estrutural dada pelas determinações da crise do coronavírus, coloca como necessidades imediatas: (a) o fim do governo Bolsonaro/Mourão e da sua política genocida que atinge expressamente a população negra deste país; (b) a revogação da EC 95, das MPs 927 e 936 e da reforma trabalhista; (c) o aumento do valor do auxílio emergencial, a sua extensão a outras categorias até o fim da pandemia; (d) o aumento dos investimentos nas áreas de saúde, assistência social e ciência e tecnologia; (e) o não pagamento da dívida pública e o destinamento deste orçamento para políticas efetivas de combate ao coronavírus, à fome e as desigualdades sociais, de forma geral; (f) a manutenção do isolamento horizontal e a garantia dos empregos e salários; (g) a garantia do fornecimento de água, energia, internet e gás gratuita à população mais precarizada; (h) saneamento básico a toda população; (i) moradia, alimentação e insumos de higiene pessoal às pessoas em situação de rua; (j) política de assistência à comunidade LGBT.

Em relação às mulheres, reconhecemos como necessidade: (a) a criação de canais online de denúncia com facilidade de acesso às vítimas de violência de gênero; (b) a ampliação das concessões de medidas protetivas; (c) a criação e a manutenção de abrigos e lares às mulheres em situação de violência; (d) a liberação remunerada das trabalhadoras domésticas que continuam em exercício; (e) assistência psicológica gratuita às mulheres da classe trabalhadora.

Do ponto de vista histórico, é necessário superar essa lógica de dominação-exploração e opressão patriarcal naturalizada ao longo da história. O real desenvolvimento de uma vida humana em sociedade é mediada por múltiplas determinações que extrapolam o plano do natural e se constitui de dimensões sociais, culturais, políticas e econômicas. A mulher não pode ser compreendida como algo pronto, dada pela natureza dessa ou daquela forma, inerte, imutável; "a essência humana não é uma abstração intrínseca ao indivíduo isolado. Em sua realidade, ela é o conjunto das relações sociais” (MARX E ENGELS, 2007. p. 538). 
Por isso, é fundamental que superemos por incorporação as explicações dos fenômenos e dados da realidade, do debate de raça, gênero e classe, e nos organizemos em torno de um projeto de superação da ordem vigente. Entendemos que para isso é necessário compreender a relação dialética entre estrutura e superestrutura, entre a esfera econômica e as esferas política, jurídica e ideológica. Sabemos que não é fácil, sobretudo num contexto como este, em que giramos todas as nossas forças para nos manter vivos. As noites parecem eternas, as vidas se perdem por nada e o futuro é incerto; a classe parece não reagir e a luta aparece apenas como lembrança; a história se repete como farsa e parece apagar de nossas memórias as nossas conquistas. Por vezes nos perguntamos se vale apena. Mas é exatamente em momentos como esses, quando marchamos com aqueles que ousam sonhar futuros, que entendemos que vale a pena viver lutando por outro projeto de sociedade. Uma sociedade livre de todas as formas de exploração-dominação e opressão.

\section{Referências}

ALMEIDA, Silvio Luiz de. Prefácio. In: HAIDER, Asad. Armadilha da identidade. raça e classe nos dias de hoje. São Paulo: Veneta, 2019.

ALMEIDA, Silvio Luiz de. Racismo estrutural. São Paulo: Sueli Carneiro. Editora Jandaíra, 2020.

ANTUNES, Ricardo. Marx em tempos de pandemia. 2020. (46m31s) In: IDEIAS DE ESQUERDA INTERNACIONAL. Disponível em:

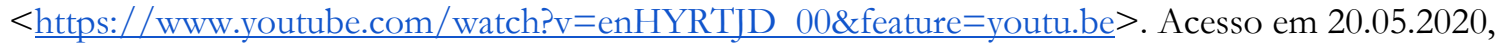
$14 \mathrm{~h} 35 \mathrm{~min}$.

BARATA-MOURA, José. Sentido de uma revisitação ontológica. In: BRANDÃO DA LUZ, J.L. (Org.).

Caminhos do pensamento Estudos em Homenagem ao professor José Enes. Lisboa: Edições

Colibri/Universidade dos Açores, 2006. p. 121-141.

DAVIS, Angela. Mulheres, raça e classe. São Paulo: Boitempo, 2016.

ENGELS, Friedrich. A origem da família, da propriedade privada e do Estado. $3^{a}$ ed. São Paulo. Expressão Popular, 2012.

HAIDER, Asad. Armadilha da identidade: raça e classe nos dias de hoje. São Paulo: Veneta, 2019.

HOOKS, Bell. O feminismo é para todo mundo: políticas arrebatadoras. $1^{a}$ ed. Rio de Janeiro: Rosa dos Tempos, 2018.

KOLLONTAI, Alexandra. A Nova mulher e a moral sexual. Editora Expressão Popular. São Paulo. 2005.

LEONTIEV, Alexis. O desenvolvimento do psiquismo. Lisboa: Horizonte, 1978.

MARCHEL, Samora. A libertação da mulher é uma necessidade da revolução, garantia da sua continuidade, condição do seu triunfo. V. 1. Textos da Revolução. Editora INOVA. 1973.

MARX, Karl. ENGELS, Friedrich. A Ideologia Alemã. São Paulo: Boitempo, 2007.

MARX, Karl. O capital: crítica da economia política: Livro I: O processo de produção do capital. São Paulo: Boitempo, 2013.

MARX, Karl. O 18 de brumário de Luís Bonaparte. São Paulo: Boitempo, 2011.

MENDES, Áquila; CARNUT, Leonardo. Lucro ou vidas? Coronavírus e o voto de Minerva. Revista Movimento.Versão Online. Publicado em: 04.2020. Disponível 
em:https://movimentorevista.com.br/2020/04/lucro-ou-vidas-coronavirus-e-o-voto-de-minerva/. Acesso em: 07. 10. 2020, às 13h10min.

MENEZES, SÓCRATES. A pandemia e a economia da morte. Publicado em 16 de abril de 2020. PCB PARTIDO COMUNISTA BRASILEIRO. Disponível em: < https//pcb.org.br/portal2/25358/a-pandemiae-a-economia-da-morte/>. Acesso em: 18.04.2020,11h33min.

PEIXOTO, Elza Margarida de Mendonça et al. Crise do Capital, Crise Sanitária, Crise Política - Notas de Conjuntura e Educação. Germinal: Marxismo e Educação em Debate, Salvador, v. 11, n. 3, p. 30-73, dez. 2019.

SAFFIOTI, Heleieth I.B. Contribuições feministas para o estudo da violência de gênero. DOSSIÊ: FEMINISMO EM QUESTÃO, QUESTÕES DO FEMINISMO. CADERNOS PAGU (16) 2001: pp.115136.

SAFFIOTI, Heleieth I.B. O poder do macho. São Paulo: Moderna, 1987.

VYGOTSKI, L. S. Obras escogidas. Problemas del desarrollo de la psique. Madrid, Cofás Móstoles, 2012 (Tomo III)

\section{Notas:}

${ }^{1}$ Professora da Rede Superior Privada de Ensino; Mestra em Educação pelo Programa de Pós-Graduação em Educação da Universidade Estadual de Feira de Santana. E-mail: ariana.rochac@gmail.com/ lattes: http://lattes.cnpq.br/2906827912132297.

2 Professora da Educação Básica da Rede Estadual de Ensino da Bahia; Mestra em Educação pela Faculdade de Educação da Universidade Federal da Bahia; Membro do Grupo de Estudos e Pesquisa Marxismo e Políticas de Trabalho e Educação (GEPMTE/UFBA).E-mail: nmbispo27@gmail.com/lattes: http://lattes.cnpq.br/0324857420036112.

3 Iasi, Mauro Luis. Meta amor fases: coletânea de poemas/Mauro Luis Iasi. 2. Ed. São Paulo: Expressão Popular, 2011. 192 p.

${ }^{4}$ GIRARDI, Giovana. OMS declara pandemia de novo coronavírus; mais de 118 mil casos foram registrados. O ESTADO DE SÃO PAULO. Publicado em 11 de março de 2020. Disponível em: < https://saude.estadao.com.br/noticias/geral,oms-declara-pandemiade-novo-coronavirus-mais-de-118-mil-casos-foram-registrados, 70003228725 >. Acesso em: 16.04.2020, 19h13min.

5CORONAVÍRUS: o mapa que mostra o alcance mundial da doença. BBC NEWS BRASIL. Disponível em: $<$ https://www.bbc.com/portuguese/internacional-51718755>. Acesso em: 04.10.2020, 19h39min.

${ }^{6}$ ZARAMELA, Luciana. As piores pandemias da história. CANALTECH. Disponível em: $<$ https://canaltech.com.br/saude/as-piorespandemias-da-historia-164788/>Acesso em: 04.10.2020, 10h45min.

7 BEDINELLI, Talita. Por que o sarampo voltou e já causou três mortes em São Paulo. EL PAÍS. Publicado em 01.09.2019. disponívem em < https://brasil.elpais.com/brasil/2019/08/30/ciencia/1567186275 036503.html>. Acesso em 22.07.2020, 20h43min.

${ }^{8}$ Movimento antivacina é uma das dez ameaças para a saúde mundial. SOCIEDADE BRASILEIRA DE MEDICINA TROPICAL. Disponível em: : <https://www.sbmt.org.br/portal/anti-vaccine-movement-is-one-of-ten-threats-to-global-health/>Acesso em: 04.10.2020, 13h05min

${ }^{9}$ GOPINATH, Gita. A economia mundial: Desaceleração sincronizada, perspectivas precárias. INTERNATIONAL MONETARY FUND. Disponível em: < https://www.imf.org/pt/News/Articles/2019/10/15/blog-weo-the-world-economy-synchronizedslowdown-precarious-outlook $>$. Acesso em 17.10.2020, 20h32min.

10 O que é desemprego. IBGE. Disponível em: <https://www.ibge.gov.br/explica/desemprego.php>. Acesso em 22.05.2020. $21 \mathrm{~h} 30 \mathrm{~min}$.

11 Pandemia afeta principalmente trabalhadores mais precarizados. DIEESE. Disponível em: < https://www.dieese.org.br/boletimempregoempauta/2020/boletimEmpregoEmPauta16.html. > Acesso em 29.10.2020. 14h26min.

12 BC anuncia nova liberação de recursos para os bancos; impacto total pode chegar a $\mathrm{R} \$ 1,2$ trilhão. G1. Disponível em: $<$ https://g1.globo.com/economia/noticia/2020/03/23/bc-muda-compulsorio-e-libera-temporariamente-r-68-bilhoes-ao-mercadofinanceiro.ghtml>. Acesso em 23.05.2020, 22h48min.

${ }_{13}$ GOVERNO libera mais R \$25,7 bi para auxílio emergencial. IG. Disponível em: <https://economia.ig.com.br/2020-04-24/governolibera-mais-r-257-bi-para-auxilio-emergencial.html>. Acesso em 23.05.2020, 22h42min.

${ }^{14}$ https://www.dieese.org.br/analisecestabasica/salarioMinimo.html

15 GULLAR, Ferreira. NÃO HÁ VAGAS. Disponível em: <https://www.tudoepoema.com.br/ferreira-gullar-nao-ha-vagas/>. Acesso em 29.10.2020. 08h42min. 
16 ATO pró-Bolsonaro em Brasília reúne manifestantes em defesa de medidas inconstitucionais. G1. Disponível em: < https://g1.globo.com/politica/noticia/2020/05/31/manifestantes-fazem-ato-em-brasilia-em-apoio-a-bolsonaro-e-em-defesa-demedidas-inconstitucionais.ghtml >. Acesso em: 31.05.2020, 21h14min.

17 BERCITO, DIOGO. Pandemia democratizou poder de matar, diz autor da teoria da 'necropolítica'. FOLHA DE SÃO PAULO. Disponível em: < https://www1.folha.uol.com.br/mundo/2020/03/pandemia-democratizou-poder-de-matar-diz-autor-da-teoria-danecropolitica.shtml>. Acesso em 30.05.2020, 08h30min.

${ }_{18}$ NOGUEIRA, Kleiton. Financiamento da saúde pública brasileira: compreendendo o desmonte do SUS. ESQUERDA DIÁRIO. Disponível em: <http://www.esquerdadiario.com.br/Financiamento-da-saude-publica-brasileira-compreendendo-o-desmonte-do-

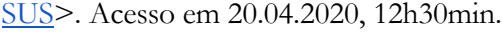

${ }^{19}$ Idem

20 PROFISSIONAIS da saúde reclamam da falta de equipamentos de proteção individual. G1. Disponível em: <https://g1.globo.com/jornal-nacional/noticia/2020/04/11/profissionais-da-saude-reclamam-da-falta-de-equipamentos-deprotecao-individual.ghtml >. Acesso em 22.05.2020, 23h20min.

21 OS 6 maiores desafios que a saúde pública do mundo vem enfrentando. CEEN. Disponível em: < $\underline{\text { https://www.ceen.com.br/os-6- }}$ maiores-desafios-que-a-saude-publica-do-brasil-vem-enfrentando/>. Acesso em 20.05.2020, 23h44min.

22 Este último revela outra contradição, que é a falta de investimento em ciência e tecnologia. O governo federal reduziu, na proposta de orçamento para 2020, 15\% os recursos para o Ministério da Ciência, Tecnologia, Inovação e Comunicações (corte de 2,3 bilhões em relação ao ano anterior). Além do mais, quase $40 \%$ da verba destinada ao Ministério está bloqueada como reserva de contingência, podendo ser usada em outras áreas. Soma-se a isso os cortes e as restrições na concessão de bolsas de pesquisa, o que potencializa ainda mais a nossa deficiência na produção de insumos hospitalares, por exemplo, e a nossa dependência às importações. Fonte: SOARES, João. In: Cortes na ciência comprometem respostas à Covid-19 no Brasil. DW. Disponível em: $<\underline{\mathrm{https}}$ :/ $/ \mathrm{www}$.dw.com/ptbr/cortes-na-ci\%C3\%AAncia-comprometem-resposta-\%C3\%A0-covid-19-no-brasil/a-53052021>. Acesso em 25.05.2020, $15 \mathrm{~h} 25 \mathrm{~min}$.

23 DIREITOS trabalhistas: as mudanças trazidas pela MP 927/2020 e 936/2020. JUSBRASIL. Disponível em: $<$ https://ndmadvogados.jusbrasil.com.br/artigos/828875899/direitos-trabalhistas-as-mudancas-trazidas-pela-mp-927-2020-e-936$\underline{2020}>$. Acesso em 30.05.2020, 17h45min.

24 BRASIL tem 6,9 milhões de famílias sem casa e 6 milhões de imóveis vazios, diz urbanista. BBC NEWS. Disponível em: $<$ https://www.bbc.com/portuguese/brasil-44028774> . Acesso em 25.05.2020, 19h10min.

25 CONDIÇÕES precárias de moradia dificultam isolamento vertical nas periferias. BRASIL DE FATO. Disponível em: $<$ https://www.brasildefato.com.br/2020/05/05/condicoes-precarias-de-moradia-dificultam-isolamento-vertical-nas-periferias $>$. Acesso em 30. 05. 2020, 18h23min.

${ }_{26}$ POPULAÇÃO em Situação de Rua. GOVERNO FEDERAL. Disponível em: < $\underline{\text { https://www.gov.br/mdh/pt-br/navegue-por- }}$ temas/populacao-em-situacao-de-rua/populacao-em-situacao-de-rua >. Acesso em 25.05.20220, 15h05min.

27 BRASIL tem 48\% da população sem coleta de esgoto, diz Instituto Trata Brasil. Fonte: AGÊNCIA SENADO. Disponível em: <https://www12.senado.leg.br/noticias/materias/2019/09/25/brasil-tem-48-da-populacao-sem-coleta-de-esgoto-diz-institutotrata-brasil >. Acesso em 22.05.2020, 21h45min.

28 COVID-19 e a População em Situação de Rua: da saúde à segurança pública?. UFRGS. Disponível em: $<$ https://www.ufrgs.br/ifch/index.php/br/covid-19-e-a-populacao-em-situacao-de-rua-da-saude-a-seguranca-publica $>$. Acesso em 25.05.2020, 21h15min.

29 POPULAÇÃO negra e Covid-19: desigualdades sociais e raciais ainda mais expostas. ABRASCO. Disponível em: $<$ https://www.abrasco.org.br/site/noticias/sistemas-de-saude/populacao-negra-e-covid-19-desigualdades-sociais-e-raciais-aindamais-expostas/46338/>. Acesso em 27.05.2020, 15h10min.

${ }^{30}$ FAVELA, questão negra e coronavírus: apontamentos marxistas sobre o negro e a luta de classes. ESQUERDA DIÁRIO. Disponível em: $\quad<$ http://www.esquerdadiario.com.br/Favela-questao-negra-e-coronavirus-apontamentos-marxistas-sobre-o-negro-e-a-luta-declasses $>$. Acesso em 27.05.2020, 17h25min.

31 POPULAÇÃO negra e Covid-19: desigualdades sociais e raciais ainda mais expostas. ABRASCO. Disponível em: $<$ https://www.abrasco.org.br/site/noticias/sistemas-de-saude/populacao-negra-e-covid-19-desigualdades-sociais-e-raciais-aindamais-expostas/46338/>. Acesso em 27.05.2020,18h00min

32 Governo lança concurso de máscara infantil e prêmio inclui café com primeira dama. UOL NOTÍCIAS. Disponível em $<$ https://noticias.uol.com.br/saude/ultimas-noticias/redacao/2020/05/07/governo-lanca-concurso-de-mascara-infantil-e-premioinclui-cafe-com-1-dama.htm >. Acesso em 30.05.2020, 17h25min.

33 CARINO, Giselle; DINIZ, Débora. Patroas, empregadas e coronavírus. EL PAÍs. Disponível em:

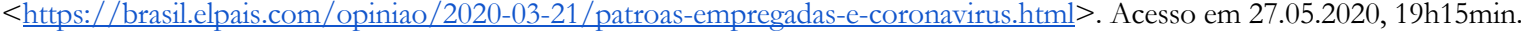

34 ANUÁRIO Brasileiro de Segurança Pública. FÓRUM BRASILEIRO DE SEGURANÇA PÚBLICA. Disponível em: $<$ http://www.forumseguranca.org.br/wp-content/uploads/2020/03/Anuario-2019-FINAL 21.10.19.pdf>. Acesso em: 28.05.2020, $14 \mathrm{~h} 54 \mathrm{~min}$. 


35 Atlas $\quad$ da $\quad$ violência $2018 . \quad$ IPEA. $\quad$ Disponível em:
$<$ https://www.ipea.gov.br/portal/images/stories/PDFs/relatorio institucional/180604 atlas da violencia 2018.pdf $>$. Acesso em 30.05.2020, 17h53min.

36 FRANCO, LUIZA. Violência contra a mulher: novos dados mostram que 'não há lugar seguro no Brasil'. BBC NEWS. Disponível em: <https://www.bbc.com/portuguese/brasil-47365503>. Acesso em 29.05.2020, $20 \mathrm{~h} 51 \mathrm{~min}$.

37 VIOLÊNCIA contra a mulher aumenta em meio à pandemia; denúncias ao 180 sobem 40\%. ESTADÃO. Disponível em: $<$ https://brasil.estadao.com.br/noticias/geral,violencia-contra-a-mulher-aumenta-em-meio-a-pandemia-denuncias-ao-180-sobem40,70003320872>. Acesso: 27.05.2020, 18h 27min.

38 NOTA técnica. Violência doméstica durante a pandemia de convid-19. $2^{\text {a }}$ ed. 29 de maio. FÓRUM BRASILEIRO DE SEGURANÇA PÚBLICA. Disponível em: < http://forumseguranca.org.br/wp-content/uploads/2020/06/violencia-domesticacovid-19-ed02-v5.pdf>. Acesso em: 01.06.2020, 23h00min.

${ }^{39}$ São Paulo, Rio de Janeiro, Minas Gerais, Espírito Santo, Acre, Amapá, Pará, Ceará, Rio Grande do Norte, Maranhão, Rio Grande do Sul e Mato Grosso.

40 "MODELO ideal de Sociedade é com mulheres apenas em casa", diz ministra inimiga das mulheres. ESQUERDA DIÁRIO. Disponível em <https://www.esquerdadiario.com.br/Modelo-ideal-de-sociedade-e-com-mulheres-apenas-em-casa-diz-ministrainimiga-das-mulheres $>$. Acesso em 28.05.2020, 18h00min.

${ }^{41}$ Usa-se o conceito de dominação-exploração ou exploração-dominação porque se concebe o processo de sujeição de uma categoria social com duas dimensões: a da dominação e a da exploração. No fenômeno do abuso sexual, por exemplo, pode haver exploração econômica, quando o abuso visa à prostituição de outrem, como também pode haver exclusivamente a obtenção de benefícios próprios, como o prazer, sem vantagens financeiras. Assim, prefere-se entender exploração-dominação como um único processo, com duas dimensões complementares (SAFFIOTI, 2001. p. 117).

42 Termo utilizado por Saffioti (1987) na obra O poder do macho.

${ }^{43}$ MULHERES dedicam quase o dobro do tempo dos homens em tarefas domésticas. AGÊNCIA IBGE NOTÍCIAS. Disponível em: $<$ https://agenciadenoticias.ibge.gov.br/agencia-noticias/2012-agencia-de-noticias/noticias/24267-mulheres-dedicam-quase-odobro-do-tempo-dos-homens-em-tarefas-domesticas $>$. Acesso em 28.05.2020., 18h30min.

44 IBGE diz que mulher é a principal responsável por criança no domicílio. AGÊNCIA BRASIL. Disponível em: <https://agenciabrasil.ebc.com.br/economia/noticia/2017-03/ibge-mulher-\%C3\%A9-principal-responsavel-pela-crianca-nodomilicio >. Acesso em 28.05.2020, 21 h00min.

${ }^{45}$ MULHERES negras precisam de dedicar à casa mais que as brancas, diz IBGE. UOL. FOLHA DE SÃO PAULO. Disponível em: < https://www1.folha.uol.com.br/mercado/2020/06/mulheres-negras-precisam-se-dedicar-a-casa-mais-que-as-brancas-dizibge.shtml >. Acesso em 04.06.2020,14h00min.

46 WENTZEL, Marina. O que faz o Brasil ter a maior população de domésticas do mundo. BBC NEWS BRASIL. Disponível em: $<$ https://www.bbc.com/portuguese/brasil-43120953> Acesso em: 29.05.2020,14h05min.

47 "Pela vida de nossas mães", dizem filhas e filhos de empregadas domésticas em manifesto. MíDIA NINJA. Disponível em: $<$ https://midianinja.org/news/pela-vida-de-nossas-maes-dizem-filhas-e-filhos-de-empregadas-domesticas-em-manifesto/>. Acesso em: 29.05.2020, 18h05min.

${ }^{48}$ FREIRE, Simone. De escravas à cuidadoras: mulheres negras na linha de frente da luta pela saúde em tempos de pandemia. ALMA PRETA JORNALISMO PRETO E LIVRE. Disponível em: < https://almapreta.com/editorias/o-quilombo/de-escravizadas-acuidadoras-mulheres-negras-na-linha-de-frente-da-luta-pela-saude-em-tempos-de-pandemia $>$. Acesso em 30.05.2020, $23 \mathrm{~h} 52 \mathrm{~min}$.

${ }^{49} \mathrm{Idem}$

50 CANDIDO, Marcia Rangel e CAMPOS, Luiz Augusto. Pandemia reduz submissões de artigos acadêmicos assinados por mulheres. ANPED. Disponível em: <http://www.anped.org.br/news/pandemia-reduz-submissoes-de-artigos-academicos-assinados-pormulheres >. Acesso em 30.05.2020, 22h00min.

Recebido em: 04.06.2020

Aprovado em: 26.10 .2020 